\title{
Solvent-less Synthesis, Antimalarial and Toxicity Evaluation of Lumefantrine-Copper Complex in Swiss Mice
}

\author{
Rotimi O. ARISE ${ }^{1 *}$, Adedibu C. TELLA², Oluyinka A. IYIOLA³, \\ Oluwakemi M. AYENI ${ }^{1}$, Samuel T. FAROHUNBI ${ }^{1}$, Abeeb A. YEKEEN ${ }^{1}$ \\ ${ }^{1}$ University of Ilorin, Faculty of Life Sciences, Department of Biochemistry, Ilorin, \\ Nigeria; ariserotimi@gmail.com ("correspondingauthor);kemycross@yahoo.com;farohunbi.st@gmail.com; abeeb.yekeen@hotmail.com \\ ${ }^{2}$ University of Ilorin, Faculty of Physical Sciences, Department ofChemistry, Ilorin, Nigeria; ac_tella@yahoo.co.uk \\ ${ }^{3}$ University of Ilorin, Faculty ofLife Sciences, Department of Zoology, Nigeria; iyiola_yinka@yahoo.com
}

\begin{abstract}
The antimalarial efficacy and safety of mechanically induced solventlessly synthesized lumefantrine-copper complex were investigated in experimental mice. Parasite level in Plasmodium berghei-infected mice treated with lumefantrine - copper complex (LCC) significantly declined $(\mathrm{p}<0.05)$ at day 3 and was comparable with that of chloroquine-treated mice. LCC attained a percentage chemo-suppression which was significantly higher than those of pure lumefantrine and comparable with chloroquine. Pure lumefantrine attained a clearance of 88.52\%, chloroquine was $91.95 \%$, while LCC was $95.10 \%$. Administration of lumefantrine, LCC and chloroquine to mice for 7 days caused a significant increase $(\mathrm{p}<0.05)$ in the activities of alkaline phosphatase, acid phosphatase and lactate dehydrogenase in the liver when compared with the control, and a significant reduction $(\mathrm{p}<0.05)$ in the liver and kidney activities of alanine and aspartate aminotransferases when compared with the control. Also, there was a significant decrease $(\mathrm{p}<0.05)$ in the levels of PCV, Hb, RBC and lymphocytes and a significant increase $(\mathrm{p}<0.05)$ in the white blood cells count and neutrophil counts in all the treatment groups when compared with control. Alterations in the biochemical parameters and chromosomal aberration in the organs investigated suggested selective, chromosomal and functional toxicity of the tested drugs.
\end{abstract}

Keywords: chloroquine, chromosomal aberration, lumefantrine-copper complex, malaria, solvent-less synthesis

Abbreviations: ALT - alanine aminotransferase, AST - aspartate aminotransferase, b.wt. - body weight, LCC - lumefantrine copper complex, PCV - packed cell volume, Hb - haemoglobin level, WBC - white blood cells count, RBC - red blood cell count, MCV - mean corpuscular volume, $\mathrm{MCH}$ - mean corpuscular, TNMA - total number of metaphases analysed, MCA metaphases with chromosomal aberration, $\mathrm{MI}$ - mitotic index, CA - chromosomal aberration

\section{Introduction}

Studies have shown that in Africa, Nigeria has one-fourth of all malaria cases (WHO, 2014). All through the year, transmission occurs in Southern Nigeria, while it is more seasonal in the North. Malaria, a life-threatening disease, occurs as a result of bites of infected female mosquitoes. About 214 million cases were reported in 2015, while there was about $37 \%$ global decrease in malaria incidence between 2000 and 2015 (WHO, 2015). It is caused by the parasitic unicellular protozoans that belong to the genus Plasmodium. Usually, the disease is transmitted through a bite from an infected female Anopheles mosquito, which introduces the parasite into the human circulatory system (WHO, 2014).

The menace of malaria has resulted in a reduced economic development in African countries by $1.3 \%$ per year (AsensoOkyere et al., 2011). Due to the accumulated effects of over 35 years, the gross domestic product of African countries, particularly Nigeria, is now approximately $32 \%$ lower than it would be expected to be without malaria (WHO, 2013). 85$90 \%$ of malaria fatalities are found in sub-Saharan Africa (Layne, 2006). Ivory Coast (86.15\%), Angola (56.93\%) and Burkina Faso (50.66\%) were estimated in 2009 to have the highest death rate per 100,000. In 2010, a study estimated that Burkina Faso, Mozambique and Mali had the deadliest cases of malaria (Murray et al., 2012).

Oral medications are available for the therapy of uncomplicated malaria (WHO, 2015). The use of artemisinins in conjunction with other antimalarial drugs (in a therapeutic approach referred to as artemisinin-combination therapy, ACT) is the most efficient therapeutic approach for $P$. falciparum infection, which also results in reduced resistance to any single drug component. Examples of these additional antimalarials are: lumefantrine, amodiaquine, sulfadoxine / pyrimethamine or mefloquine (WHO, 2001). The incessant spread of resistance of $P$. falciparum to antimalarial drugs presents a menace to malaria control plans (Adebayo and Krettli, 2011). 
Lumefantrine is an antimalarial drug used to treat acute uncomplicated malaria. It is administered in a combination therapy in conjunction with artemether, for enhanced effectiveness (Omari et al., 2003). The mechanism of action of the combination therapy involves activity against the erythrocytic stages of Plasmodium spp. and is thus employed for the treatment of $P$. falciparum infections and unidentified Plasmodium species, including infections acquired in chloroquine-resistant areas (Omari et al., 2006). Lumefantrine, an aryl-amino alcohol (Aweeka and German, 2008), prevents detoxification of heme. Toxic heme and free radicals bring the death of malaria parasite (Kokwaro et al., 2007).

As a result of environmental pollution, related to solvent disposals and reduced sources of energy supply, it was required the developing of benign synthetic pathways which are simple and exhibit high atom economy (Cave et al., 2001). Mechanochemical synthesis also referred to as solvent-free approach ranges from merely grinding reactants using a mortar and pestle, to ball milling procedure (Tella et al., 2011). Previous studies have shown that the effectiveness of some therapeutic agents was enhanced upon coordination to transition metals (Ogunniran et al., 2007; Tella et al., 2015). Incorporation of metallocene into each of quinine and chloroquine has been reported to produce compounds that exhibited activity against both Plasmodium chloroquinesensitive and chloroquine-resistant strains (Obaleye et al., 2009) and were reported to be safe and non-mutagenic in mice (Dormale et al., 1998).

In continuation of the authors' efforts to find new antimalarial drugs effective against chloroquine resistant strain of the malaria parasite, this work seeks to make known the biological activities (antimalarial effect and safety) of lumefantrine-copper complex.

\section{Materials and Methods}

\section{Drugsused}

Lumefantrine-copper complex was synthesized in the Department of Chemistry, University of Ilorin. Chloroquine phosphate capsules used is a product of the Tuyil Pharmaceutical Company, Ilorin, Nigeria. The active ingredient of lumefantrine used is a product of the Tuyil Pharmaceutical Company, Ilorin, Nigeria.

\section{Experimentalanimals}

Thirty white male albino mice (Mus muculus) with an average weight of $16.79 \pm 0.36$ g were obtained from the Animal Holding Unit of the Department of Biochemistry, Faculty of Life Sciences, University of Ilorin, Ilorin, Nigeria.

\section{Malariaparasite}

Plasmodium berghei (chloroquine sensitive NK-65) was obtained from the Institute for Advanced Medical Research and Training (IAMRAT), College of Medicine, University of Ibadan, Nigeria.

\section{Assay kits and reagents used}

Lactate dehydrogenase, alkaline phosphatase, aspartate aminotransferase and alanine aminotransferase assay kits were products of Randox Laboratories Ltd., United Kingdom. All other reagents used were of analytical grade and were prepared in all glass apparatus using distilled water.

\section{Mechanochemical synthesis of lumefantrine-copper complex}

A stoichiometric 1:1 mixture of copper II chloride salt (1 mole, $0.170 \mathrm{~g}$ ) and lumefantrine ( 1 mole, $0.450 \mathrm{~g}$ ) was manually grounded in an agate mortar which had been washed and cleaned before use (Fig. 1). The reactants were pulverized for 15 minutes to yield a yellow substance. Drops (2) of methanol were added to make a more homogenous complex resulting in a pale green complex. Evolution of gases and colour changes were observed. The powder was collected for melting point, infrared spectra and X-ray Powder Diffraction (XPRD) analyses.

\section{Inoculation of experimental mice}

Each mouse in the infected groups (20 mice, 5 per group) was inoculated intraperitoneally with $0.2 \mathrm{ml}$ of infected blood containing about $1 \times 10^{7} P$. berghei parasitized red blood cells. Blood smear was prepared, stained and observed under the microscope to establish parasitaemia on the fifth day after inoculation (Ryley and Peters, 1970).

\section{Experimental design}

Anti-malarial study was investigated in mice. The rats were supplied with normal rat chow and water ad libitum. The experimental animals were randomly divided into six groups as follows:

Group 1: not treated, not infected - Control (C);

Group 2: infected but not treated (IU);

Group 3: infected and treated with chloroquine (IC);

Group 4: infected and treated with lumenfantrine (IL);

Group 5: infected and treated with lumenfantrine- $\mathrm{Cu}$ (IC);

Group 6: Not infected but treated with lumenfantrine-Cu (NILC)

The mice in groups 1 and 2 were administered $0.2 \mathrm{ml}$ of distilled water. Mice in group 3 were administered $0.2 \mathrm{ml}$ of 5.5 $\mathrm{mg} / \mathrm{kg}$ b.wt. chloroquine. Other groups were administered 0.2 $\mathrm{ml}$ of each drug corresponding to $1.71 \mathrm{mg} / \mathrm{kg}$ body weight for a period of 3 days respectively. All experimental animals were sacrificed 24 hours after their last doses.

\section{Curative tests}

The design adopted was the method modified by Ryley and Peters (1970). This was carried out by passaging of the experimental mice with standard inoculums of rodent $P$. berghei and confirmation of establishment of malaria parasite infection 72 hours post-infection before the commencement of treatment.

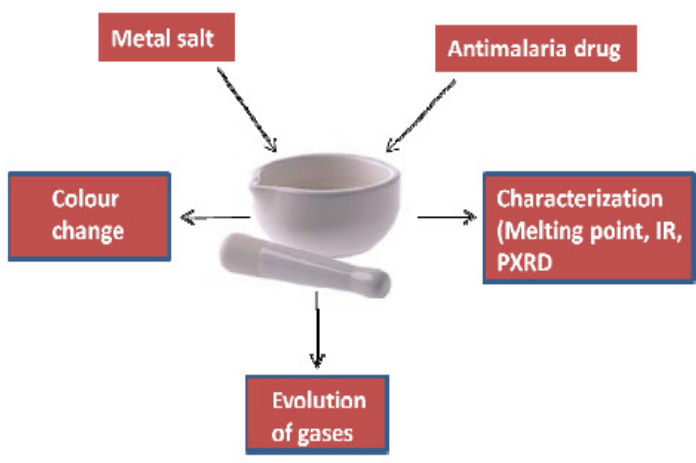

Fig. 1. Schematic diagram of mechanochemical synthesis (grinding) 
294

The preparation of slides started 24 hours after the first treatment.

\section{Toxicity evaluation}

\section{Enzyme assays}

The procedure described by Roy (1970) was used to assay alkaline phosphatase (ALP) activity. Aspartate aminotranferase (AST) and alanine aminotranferase (ALT) activities were assayed using the method of Reitman and Frankel (1957). Lactate dehydrogenase activity was measured following the method of Kubowitz and Ott (1943) as modified by Wroblewski and La Due (1955). Acid phosphatase activity was measured as described by Wright et al. (1972).

\section{Hematological parameters}

Packed cell volume (PCV), haemoglobin level $(\mathrm{Hb})$, white blood cells count (WBC), mean corpuscular haemoglobin concentration (MCHC) and platelet count were determined using the methods of Adewuyi and Olatunji (1995).

\section{DNA damage and chromosomal aberration evaluation}

Chromosomal aberration analysis was carried out using the method described by Bakare (2009). Kidney and liver samples were homogenized in $5 \mathrm{ml}$ of $0.56 \% \mathrm{KCl}$ and left at room temperature $\left(25^{\circ} \mathrm{C}\right)$ for 30 minutes. The cell suspension was quickly overlaid with $1 \mathrm{ml}$ freshly prepared chilled Carnoy's fixative and was gently mixed with a vortex mixer. Centrifugation was done at 2,000 rpm for 10 minutes. The supernatant was pipetted into a clean tube and slowly overlaid with $0.5 \mathrm{ml}$ freshly prepared chilled Carnoy's fixative. The tubes were kept at $4{ }^{\circ} \mathrm{C}$ for 30 minutes through fixation; the contents were gently mixed and centrifuged at 2,000 rpm for 10 minutes. The supernatant was gently removed without disturbing the pellets and fresh fixative was added. The fixing and centrifuging was done twice until a clear transparent cell suspension was obtained. A pipette was used to drop a small quantity of the cell suspension onto grease free, pre-cleaned glass slides. The slides were air dried and stained with 5\% Giemsa stain for 20 minutes. The slides were made permanent by dipping them in xylene and then drops from Canada balsam were added and covered with slips, metaphase spreads were observed at a magnification of 1000x.

\section{Statistical analysis}

Data were expressed as means of 5 replicates. Data from the test groups were compared with their respective controls and differences were considered significant at $\mathrm{p}<0.05$. Statistical analysis was determined using ANOVA and DUNCAN's multiple range tests (Mahajan, 1997).

\section{Results}

The complex synthesized had a yellow colour and a melting point of $115^{\circ} \mathrm{C}$. It was soluble in methanol and distilled water. Infrared spectra data also revealed that lumefantrine behaved as a ligand with donor sequence towards copper ions, with which coordination took place. The metal chloride salt reacted with the ligand "L" forming a complex using the proposed equation:

$\mathrm{MX}_{2}+\mathrm{L}=\mathrm{ML} \cdot \mathrm{X}_{2}$

Where: $\mathrm{M}$ represents $\mathrm{Cu}^{2+}$ metal salt; $\mathrm{L}$, lumefantrine and $\mathrm{X}$, Chloride ion.
Infrared spectra of lumefantrine-copper complex are shown in Fig. 2.

Table 1 shows parasitaemia levels in P. berghei NK-65 infected mice treated with chloroquine, pure lumefantrine and lumefantrine - copper complex. There was a significant increase $(\mathrm{p}<0.05)$ in parasitaemia in the IU group at days 2 and 3 post-inoculation when compared to other groups. The parasite level in mice treated with lumefantrine - copper complex significantly declined $(\mathrm{p}<$ 0.05 ) on day 3 when compared to previous days and was significantly lower than the parasitaemia in animals of the untreated group. The percentage of parasitaemia reduction in animals treated with lumefantrine (pure and copper complex) groups was comparable with that of the standard drug (chloroquine).

Table 2 shows the percentage chemo-suppression of parasite multiplication in $P$. berghei NK-65-infected mice treated with chloroquine, pure lumefantrine and lumefantrine - copper complex. The percentage chemosuppression attained by lumefantrine - copper complex was significantly higher $(\mathrm{p}<0.05)$ than pure lumefantrine

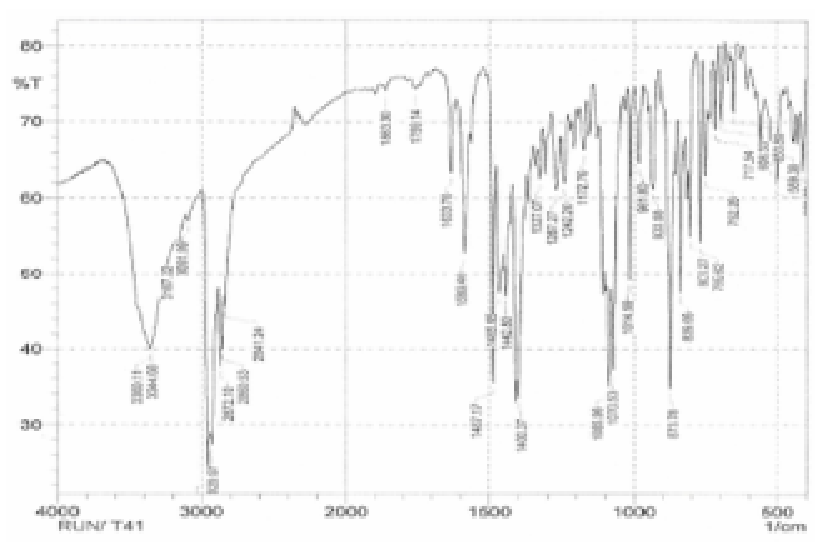

Fig. 2. Infrared spectra of lumefantrine - copper complex

Table 1. Parasitaemia levels in P. berghei NK-65 infected mice treated with chloroquine, pure lumefantrine and lumefantrine - copper complex

\begin{tabular}{cccc}
\hline Group & Day 1 (\%) & Day 2(\%) & Day 3(\%) \\
\hline IU & $22.99 \pm 0.72^{\mathrm{a}}$ & $34.40 \pm 0.59^{\mathrm{c}}$ & $45.86 \pm 0.82^{\mathrm{b}}$ \\
IC & $22.38 \pm 0.43^{\mathrm{a}}$ & $15.60 \pm 0.32^{\mathrm{b}}$ & $13.06 \pm 0.62^{\mathrm{a}}$ \\
IL & $22.41 \pm 0.64^{\mathrm{a}}$ & $18.84 \pm 0.46^{\mathrm{a}}$ & $13.71 \pm 0.61^{\mathrm{a}}$ \\
ILC & $22.37 \pm 0.58^{\mathrm{a}}$ & $18.99 \pm 0.59^{\mathrm{a}}$ & $12.32 \pm 0.60^{\mathrm{a}}$
\end{tabular}

Each value is a mean of 5 replicates \pm SEM. Rows with different superscripts were significantly different $(\mathrm{p}<0.05)$; IU - Infected untreated, IC - Infected treated with chloroquine, IL - Infected treated with lumefantrine (pure), ILC- Infected treated with lumefantrine - copper complex

Table 2. Percentage chemo-suppression of parasite multiplication in $P$. berghei NK-65 infected mice treated with chloroquine, pure lumefantrine and lumefantrine - copper complex

\begin{tabular}{ccc}
\hline Group & Day 5 (\%) & Day 7 (\%) \\
\hline IC & 53.48 & 91.95 \\
IL & 45.23 & 88.52 \\
ILC & 47.70 & 95.10 \\
\hline \multicolumn{2}{l}{ Each value is a mean of 5 replicates; IC - Infected treated with chloroquine, IL - } \\
Infected treated with lumefantrine (pure), ILC- Infected treated with
\end{tabular}
lumefantrine - copper complex 
but comparable with chloroquine. Pure lumefantrine attained a clearance of $88.52 \%$, chloroquine was $91.95 \%$, while the lumefantrine - copper complex was $95.10 \%$.

Table 3 shows the effect of lumefantrine and lumefantrine - copper complex on the specific activity of alkaline phosphatase (ALP) in the liver and plasma of $P$. berghei NK-65-infected mice. There was a significant reduction $(\mathrm{p}<0.05)$ in the activity of ALP in the liver across all groups when compared with the control (treated with distilled water). Also, in the plasma there was a significant increase $(\mathrm{p}<0.05)$ across all groups when compared with the control (treated with distilled water). Table 4 shows the effect of lumefantrine and lumefantrine - copper complex on the specific activity of aspartate aminotransferase (AST) in the liver and plasma of $P$. berghei NK-65-infected mice. There was a significant reduction $(\mathrm{p}<0.05)$ in the activity of AST in the liver across all groups when compared with the control (group administered distilled water). However, in the plasma there was a significant increase $(\mathrm{p}<0.05)$ across all groups when compared with the control (group administered distilled water).

Table 5 shows the effect of lumefantrine and lumefantrine - copper complex on the specific activity of alanine aminotransferase (ALT) in the liver and plasma of

Table 3. The effect of lumefantrine and lumefantrine - copper complex on the specific activity of alkaline phosphatase (ALP) in the liver and plasma of $P$. berghei NK-65 infected mice

\begin{tabular}{ccc}
\hline Group & Liver ALP $(\mathrm{U} / \mathrm{L})$ & Plasma ALP $(\mathrm{U} / \mathrm{L})$ \\
\hline C & $80.73 \pm 7.06^{\mathrm{c}}$ & $7.36 \pm 0.26^{\mathrm{a}}$ \\
IU & $59.08 \pm 3.97^{\mathrm{b}}$ & $5.99 \pm 0.42^{\mathrm{a}}$ \\
IC & $54.79 \pm 3.08^{\mathrm{a}}$ & $9.79 \pm 0.82^{\mathrm{b}}$ \\
IL & $60.63 \pm 4.27^{\mathrm{b}}$ & $11.23 \pm 1.01^{\mathrm{c}}$ \\
ILC & $65.27 \pm 5.40^{\mathrm{b}}$ & $12.54 \pm 1.41^{\mathrm{c}}$ \\
NLC & $54.77 \pm 4.96^{\mathrm{a}}$ & $12.20 \pm 1.42^{\mathrm{c}}$
\end{tabular}

Each value is a mean of 5 replicates \pm SEM. Columns with different superscripts were significantly different $(\mathrm{p}<0.05)$; C - Control, IU - Infected untreated, IC Infected treated with chloroquine, IL - Infected treated with lumefantrine (pure) ILC- Infected treated with lumefantrine - copper complex

Table 4. The effect of lumefantrine and lumefantrine - copper complex on the specific activity of aspartate aminotransferase in the liver and plasma of $P$. berghei NK-65 infected mice

\begin{tabular}{lcc}
\hline Group & Liver AST (U/L) & Plasma AST (U/L) \\
\hline C & $154.97 \pm 8.25^{\mathrm{d}}$ & $14.26 \pm 1.45^{\mathrm{a}}$ \\
IU & $127.41 \pm 6.14^{\mathrm{c}}$ & $18.60 \pm 1.14^{\mathrm{a}}$ \\
IC & $121.37 \pm 6.87^{\mathrm{c}}$ & $27.80 \pm 1.78^{\mathrm{b}}$ \\
IL & $124.15 \pm 5.65^{\mathrm{c}}$ & $31.85 \pm 2.89^{\mathrm{c}}$ \\
ILC & $103.19 \pm 5.71^{\mathrm{b}}$ & $35.11 \pm 2.56^{\mathrm{c}}$ \\
NLC & $81.75 \pm 4.65^{\mathrm{a}}$ & $41.35 \pm 4.83^{\mathrm{d}}$ \\
\hline
\end{tabular}

Each value is a mean of 5 replicates \pm SEM. Columns with different superscripts were significantly different $(\mathrm{p}<0.05)$; $\mathrm{C}$ - Control, IU - Infected untreated, IC Infected treated with chloroquine, IL - Infected treated with lumefantrine (pure), ILC- Infected treated with lumefantrine - copper complex
P. berghei NK-65-infected mice. There was a significant decrease $(p<0.05)$ in the activity of ALT in the liver of lumefantrine and lumefantrine - copper complex-treated groups when compared with the control (treated with distilled water). However, in the plasma there was a significant increase $(p<0.05)$ in the activity of ALT between lumefantrine and lumefantrine - copper complextreated groups when compared with the control (treated with distilled water) except in the negative control (infected untreated) and chloroquine-treated, which showed no significant difference $(p>0.05)$ in comparison with the positive control.

Table 6 shows the effect of lumefantrine and lumefantrine - copper complex on the specific activity of lactate dehydrogenase (LDH) in the liver and plasma of $P$. berghei NK-65 infected mice. There was a significant increase $(p<0.05)$ in the activity of LDH in the liver across all the groups except in the negative control where there was no significant difference when compared with the control (treated with distilled water). There was a significant increase $(\mathrm{p}<0.05)$ in the plasma LDH activity across all groups when compared with the control (treated with distilled water) except in the group treated with chloroquine, which showed no significant difference ( $p$ > 0.05 ) in comparison with the positive control.

Table 5. The effect of lumefantrine and lumefantrine - copper complex on the specific activity of liver and plasma alanine aminotransferase of $P$. berghei NK-65 infected mice

\begin{tabular}{ccc}
\hline Group & Liver ALT (U/L) & Plasma ALT (U/L) \\
\hline C & $127.98 \pm 9.38^{\mathrm{c}}$ & $6.80 \pm 0.54^{\mathrm{a}}$ \\
IU & $120.68 \pm 10.12^{\mathrm{c}}$ & $7.89 \pm 1.25^{\mathrm{a}}$ \\
IC & $125.90 \pm 10.33^{\mathrm{c}}$ & $9.79 \pm 2.51^{\mathrm{b}}$ \\
IL & $115.61 \pm 11.19^{\mathrm{b}}$ & $14.09 \pm 1.37^{\mathrm{c}}$ \\
ILC & $112.56 \pm 9.56^{\mathrm{b}}$ & $16.48 \pm 1.33^{\mathrm{c}}$ \\
NLC & $80.49 \pm 7.89^{\mathrm{a}}$ & $16.29 \pm 1.45^{\mathrm{c}}$
\end{tabular}

Each value is a mean of 5 replicates \pm SEM. Columns with different superscripts were significantly different $(\mathrm{p}<0.05)$; C - Control, IU - Infected untreated, IC Infected treated with chloroquine, IL - Infected treated with lumefantrine (pure), ILC-Infected treated with lumefantrine - copper complex

Table 6. The effect of lumefantrine and lumefantrine - copper complex on the specific activity of lactate dehydrogenase $(\mathrm{LDH})$ in the liver and plasma of P. berghei NK-65 infected mice

\begin{tabular}{ccc}
\hline Group & Liver LDH $(\mathrm{U} / \mathrm{L})$ & Plasma LDH $(\mathrm{U} / \mathrm{L})$ \\
\hline C & $16.62 \pm 1.15^{\mathrm{a}}$ & $12.78 \pm 0.73^{\mathrm{a}}$ \\
IU & $26.26 \pm 1.40^{\mathrm{a}}$ & $9.89 \pm 0.40^{\mathrm{a}}$ \\
IC & $38.46 \pm 2.70^{\mathrm{b}}$ & $18.64 \pm 1.36^{\mathrm{b}}$ \\
IL & $58.42 \pm 4.48^{\mathrm{c}}$ & $27.39 \pm 1.78^{\mathrm{c}}$ \\
ILC & $82.45 \pm 6.14^{\mathrm{d}}$ & $29.37 \pm 1.26^{\mathrm{c}}$ \\
NLC & $50.99 \pm 3.28^{\mathrm{c}}$ & $24.96 \pm 1.07^{\mathrm{c}}$ \\
\hline
\end{tabular}

Each value is a mean of 5 replicates \pm SEM. Columns with different superscripts were significantly different $(\mathrm{p}<0.05)$; C - Control, IU - Infected untreated, IC Infected treated with chloroquine, IL - Infected treated with lumefantrine (pure), ILC-Infected treated with lumefantrine - copper complex 
Table 7. The effect of lumefantrine and lumefantrine - copper complex on the concentration of some biochemical parameters in the plasma of $P$. berghei NK-

65 infected mice

\begin{tabular}{|c|c|c|c|c|c|c|}
\hline Group & $\mathrm{Na}^{+}$ & $\mathrm{K}^{+}$ & $\mathrm{Cl}^{-}$ & $\mathrm{HCO}_{3}{ }^{-}$ & Urea & Creatinine \\
\hline $\mathrm{C}$ & $100.23 \pm 2.33^{\mathrm{bc}}$ & $6.19 \pm 0.36^{a}$ & $74.88 \pm 2.14^{\mathrm{a}}$ & $16.89 \pm 0.77^{\mathrm{a}}$ & $9.36 \pm 0.54^{\mathrm{b}}$ & $12.82 \pm 3.26^{\mathrm{ab}}$ \\
\hline IU & $92.01 \pm 5.05^{b}$ & $5.48 \pm 0.37^{a}$ & $79.26 \pm 4.05^{\mathrm{a}}$ & $21.15 \pm 4.05^{b}$ & $6.57 \pm 0.13^{\mathrm{a}}$ & $9.72 \pm 0.90^{\mathrm{a}}$ \\
\hline IC & $126.68 \pm 2.08^{d}$ & $5.64 \pm 0.35^{a}$ & $93.94 \pm 1.79^{\circ}$ & $16.70 \pm 1.61^{\mathrm{a}}$ & $7.38 \pm 0.46^{\mathrm{ab}}$ & $18.20 \pm 4.39^{b}$ \\
\hline IL & $97.66 \pm 4.16^{b c}$ & $5.17 \pm 0.71^{a}$ & $91.38 \pm 3.42^{b c}$ & $21.22 \pm 1.78^{b}$ & $5.71 \pm 1.00^{\mathrm{a}}$ & $18.41 \pm 1.94^{\mathrm{b}}$ \\
\hline ILC & $103.56 \pm 2.85^{c}$ & $10.90 \pm 1.20^{\mathrm{b}}$ & $83.33 \pm 4.25^{\mathrm{a}}$ & $18.17 \pm 3.43^{\mathrm{ab}}$ & $6.11 \pm 0.85^{a}$ & $11.17 \pm 2.45^{\mathrm{ab}}$ \\
\hline NLC & $80.04 \pm 2.52^{\mathrm{a}}$ & $12.19 \pm 2.32^{b}$ & $91.17 \pm 1.22^{\mathrm{bc}}$ & $12.54 \pm 0.81^{\mathrm{a}}$ & $6.32 \pm 0.82^{a}$ & $14.08 \pm 0.40^{\mathrm{ab}}$ \\
\hline
\end{tabular}

Each value is a mean of 5 replicates \pm SEM. Columns with different superscripts were significantly different $(\mathrm{p}<0.05)$. C - Control, IU - Infected untreated, IC Infected treated with chloroquine, IL - Infected treated with lumefantrine (pure), ILC- Infected treated with lumefantrine - copper complex

Table 7 shows the effect of lumefantrine and lumefantrine - copper complex on the concentration of some biochemical parameters in the plasma of $P$. berghei NK-65-infected mice. Plasma urea concentration showed a significant decrease $(p<0.05)$ in all the groups except chloroquine-treated group which showed no significant difference $(\mathrm{p}>0.05)$ when compared with the positive control. There was no significant difference $(p>0.05)$ in the concentration of plasma creatinine in each of the groups when compared with the positive control. However, the concentration of plasma creatinine in the groups administered with chloroquine and pure lumefantrine was significantly higher $(\mathrm{p}<0.05)$ than the untreated ones, whereas there was no significant difference $(p>0.05)$ in the concentration of plasma creatinine in the group treated with lumefantrine (pure and coppercomplexed) when compared with the chloroquine-treated group and the positive control.

The concentration of sodium ion in the plasma did not show any significant alteration $(\mathrm{p}>0.05)$ in the group administered with lumefantrine (pure and coppercomplexed) when compared with the positive control. However, there was a significant increase $(\mathrm{p}<0.05)$ in the plasma sodium ion concentration of the groups administered with chloroquine. In contrast, there was no significant difference $(\mathrm{p}>0.05)$ in the plasma concentration of potassium ion across the groups except for the significant elevation $(p<0.05)$ in the groups administered with lumefantrine - copper complex. There was a significant increase $(\mathrm{p}<0.05)$ in the concentration of bicarbonate ion in the untreated group and the group administered with pure lumefantrine when compared with the positive control. The concentration of chloride ion in the plasma was significantly increased $(p<0.05)$ in each of the groups administered with chloroquine and pure lumefantrine when compared with the control, but no significant difference $(p>0.05)$ was observed in the group treated with lumefantrine - copper complex and chloroquine.

Table 8 shows the effect of lumefantrine and lumefantrine - copper complex on the concentration of some haematological parameters in the plasma of $P$. berghei NK-65 infected mice. There was a significant decrease $(p<0.05)$ in the levels of red blood cells, haemoglobin, PCV, lymphocyte, $\mathrm{MCHC}$ and $\mathrm{MCH}$ across all groups when compared with the positive control.

Table 8. Effect of lumefantrine and lumefantrine - copper complex on the concentration of some haematological parameters in the plasma of $P$. berghei NK-65 infected mice

\begin{tabular}{|c|c|c|c|c|c|c|}
\hline Parameter & $\mathrm{C}$ & IU & IC & IL & ILC & NLC \\
\hline WBC & $5.84 \pm 0.69^{a}$ & $22.2 \pm 2.75^{b}$ & $21.62 \pm 4.68^{b}$ & $21.06 \pm 1.28^{\mathrm{b}}$ & $19.40 \pm 1.82^{\mathrm{b}}$ & $6.04 \pm 0.62^{a}$ \\
\hline $\mathrm{RBC}$ & $8.60 \pm 0.44^{c}$ & $4.43 \pm 0.15^{a}$ & $7.06 \pm 0.46^{b}$ & $5.00 \pm 0.33^{a}$ & $5.06 \pm 0.57^{\mathrm{a}}$ & $7.63 \pm 0.51^{\mathrm{bc}}$ \\
\hline $\mathrm{Hb}$ & $13.54 \pm 0.56^{c}$ & $6.48 \pm 0.25^{\mathrm{a}}$ & $10.68 \pm 0.74^{b}$ & $7.64 \pm 0.54^{a}$ & $7.32 \pm 0.91^{\mathrm{a}}$ & $11.10 \pm 0.88^{\mathrm{b}}$ \\
\hline PCV & $49.16 \pm 2.47^{c}$ & $25.56 \pm 0.86^{a}$ & $40.24 \pm 2.79^{b}$ & $28.66 \pm 2.18^{a}$ & $28.70 \pm 3.34^{\mathrm{a}}$ & $41.88 \pm 3.14^{\mathrm{bc}}$ \\
\hline $\mathrm{MCV}$ & $57.16 \pm 1.08^{\mathrm{ab}}$ & $57.70 \pm 0.49^{\mathrm{b}}$ & $56.90 \pm 0.44^{\mathrm{ab}}$ & $57.24 \pm 1.13^{b}$ & $56.60 \pm 0.61^{\mathrm{ab}}$ & $54.76 \pm 0.51^{a}$ \\
\hline $\mathrm{MCH}$ & $15.78 \pm 0.27^{\mathrm{b}}$ & $14.74 \pm 0.20^{\mathrm{a}}$ & $15.10 \pm 0.17^{\mathrm{ab}}$ & $14.58 \pm 0.38^{\mathrm{a}}$ & $14.36 \pm 0.28^{a}$ & $14.48 \pm 0.20^{\mathrm{a}}$ \\
\hline $\mathrm{MCHC}$ & $27.62 \pm 0.45^{c}$ & $25.48 \pm 0.19^{\mathrm{ab}}$ & $26.52 \pm 0.14^{\mathrm{b}}$ & $25.49 \pm 0.19^{\mathrm{ab}}$ & $25.38 \pm 0.59^{a}$ & $26.48 \pm 0.24^{\mathrm{b}}$ \\
\hline $\operatorname{PLT}(\times 10)$ & $149.30 \pm 9.46^{b}$ & $40.80 \pm 9.50^{a}$ & $63.82 \pm 1.29^{a}$ & $47.00 \pm 4.61^{\mathrm{a}}$ & $41.76 \pm 5.71^{\mathrm{a}}$ & $148.94 \pm 12.03^{b}$ \\
\hline LYM & $75.48 \pm 4.18^{\mathrm{a}}$ & $75.60 \pm 0.00^{\mathrm{a}}$ & $81.32 \pm 4.89^{a}$ & $75.72 \pm 1.32^{\mathrm{a}}$ & $85.58 \pm 2.24^{a}$ & $80.90 \pm 6.72^{\mathrm{a}}$ \\
\hline
\end{tabular}

Each value is a mean of 5 replicates \pm SEM. Columns with different superscripts were significantly different $(\mathrm{p}<0.05)$; C - Control, IU - Infected untreated, IC Infected treated with chloroquine, IL - Infected treated with lumefantrine (pure), ILC-Infected treated with lumefantrine - copper complex, NLC- Not infected but treated with lumefantrine - copper complex, WBC - White blood cell count, Hb - Haemoglobin concentration, RBC - Red blood cell count, PCV - Packed cell volume, MCV - mean corpuscular volume, MCH - mean corpuscular haemoglobin, MCHC - mean corpuscular haemoglobin concentration, PLT - Platelet count, LYM Lymphocytes 
Conversely, there was a significant increase $(p<0.05)$ in the level of WBC when compared with the positive control in all the groups except the uninfected but treated with the complex group. The malaria-infected mice and treated with chloroquine and lumefantrine -copper complex groups did not show any significant difference $(p>0.05)$ in the concentration of MCV when compared with the positive control; there was however a significant increase $(\mathrm{p}<0.05)$ in the malaria-infected but untreated mice.

Tables 9 and 10 show the effect of lumefantrine and lumefantrine - copper complex on chromosomal aberration in the liver and kidney of $P$. berghei NK-65 infected mice respectively. There was no significant difference $(p>0.05)$ in the total number of metaphases analyzed (TNMA) across the groups in both the liver and kidneys when compared with the positive control. Also, there was no significant difference $(\mathrm{p}>0.05)$ between the positive control and the group administered pure lumefantrine in the amount of metaphases with chromosomal aberration (MCA); however, a significant increase $(p<0.05)$ was observed in the groups treated with lumefantrine - copper complex when compared with the control for both the liver and kidneys. The mitotic index showed no significant alteration $(\mathrm{p}>0.05)$ across the groups in both the liver and kidneys when compared with the control. In contrast, there was a significant increase ( $p$ $<0.05$ ) in the percentage chromosomal aberration across the groups except for the group treated with pure lumefantrine, that showed no significant difference $(\mathrm{p}>$ 0.05 ) when compared with the control.

\section{Discussion}

Mechanochemical or solvent-less synthesis is a simple and environmentally friendly procedure (Cave et al., 2001). The method gave about $76-78 \%$ yields within a shorter duration

Table 9. Effect of lumefantrine and lumefantrine - copper complex on chromosomal aberration in the kidney of $P$. berghei NK-65 infected mice

\begin{tabular}{ccccc}
\hline Groups & TNMA & MCA & MI & \%CA \\
\hline C & $159.00 \pm 2.00^{\mathrm{a}}$ & $2.00 \pm 0.30^{\mathrm{a}}$ & $15.90 \pm 0.20^{\mathrm{a}}$ & $1.25 \pm 0.61^{\mathrm{a}}$ \\
IU & $137.00 \pm 4.00^{\mathrm{a}}$ & $21.50 \pm 1.50^{\mathrm{b}}$ & $13.70 \pm 0.40^{\mathrm{a}}$ & $15.68 \pm 0.64^{\mathrm{b}}$ \\
IC & $148.50 \pm 2.50^{\mathrm{a}}$ & $39.00 \pm 6.00^{\mathrm{c}}$ & $14.85 \pm 0.25^{\mathrm{a}}$ & $26.09 \pm 4.74^{\mathrm{c}}$ \\
IL & $149.00 \pm 2.00^{\mathrm{a}}$ & $2.50 \pm 2.50^{\mathrm{a}}$ & $14.90 \pm 0.20^{\mathrm{a}}$ & $1.70 \pm 1.70^{\mathrm{a}}$ \\
ILC & $138.50 \pm 16.50^{\mathrm{a}}$ & $24.00 \pm 2.00^{\mathrm{b}}$ & $13.85 \pm 1.65^{\mathrm{a}}$ & $17.40 \pm 0.63^{\mathrm{bc}}$ \\
NLC & $151.00 \pm 7.00^{\mathrm{a}}$ & $39.00 \pm 3.00^{\mathrm{c}}$ & $15.10 \pm 0.70^{\mathrm{a}}$ & $25.98 \pm 3.19^{\mathrm{c}}$ \\
\hline Each value is a mean of 5 replicates \pm SEM. Columns with different superscripts \\
were significantly different (p < 0.05); TNMA - Total number of metaphases \\
analysed, MCA - Metaphases with chromosomal aberration, MI - Mitotic index, \\
\%CA - Percentage chromosomal aberration. C - Control, IU - Infected \\
untreated, IC - Infected treated with chloroquine, IL - Infected treated with \\
lumefantrine (pure), ILC- Infected treated with lumefantrine - copper complex, \\
NLC- Not infected but treated with lumefantrine - copper complex
\end{tabular}

of 15 minutes as compared to $50-60 \%$ by classical solution phase which often takes 3 hours for the reaction to complete. This result agrees with the findings of Tella et al. (2011) who reported that infrared spectra data suggested that lumefantrine behaved as a ligand with donor sequence towards copper ions, with which coordination took place. The limitation of widespread use of solvent or even the total absence of solvent in synthetic reactions is one of the main targets of green chemistry (Mikhailanko et al., 2004).

The in vivo antimalarial activity of lumefantrine - metal complex showed that lumefantrine - copper complex is more efficient in clearance of malaria parasite than pure lumefantrine. Lumefantrine - copper complex showed curative antimalarial activity comparable to chloroquine. Coordination of the metal improved the activity of the drug; this could be attributed to the complex binding first without being decomposed at the receptor site and also the deposition of free metal ion in the parasite membrane. These results agree with the findings of Biot et al. (2001) who reported that incorporation of a metal ion into a molecule gave rise to the formation of a compound with enhanced activity.

Some enzymes are present in the plasma whereas they do not originally belong in the plasma or serum. These enzymes could be present due to leakage from their original location into the plasma as a result of tissue damage. Biochemical indices that are measured in the serum, plasma and organs such as liver and kidney are useful markers in the assessment of damage to tissues. A measure of the activities of various enzymes in tissues and body fluids plays a significant function in disease diagnosis and tissue assessment (Akanji et al., 1993). ALP is a marker enzyme for the integrity of the plasma membrane of hepatocytes (Akanji et al., 1993) and the endoplasmic reticulum (Wright and Plumer, 1974; Shahjahan et al., 2004); any alteration in the activity of the enzyme either in the tissue or serum, would be indicative of a likely damage to the outer boundary of the cells. The liver and plasma activities of the enzyme (Table 3) show a significant difference between the control and the test; this may indicate that the integrity of the plasma membrane has been impaired. This may also be attributed to the stress inflicted on the tissue by the drugs, which could have resulted in leakage of the enzyme molecule through the extracellular fluid, as was significantly noticed in the plasma. In an effort to counteract this stress, de novo synthesis of the enzymes might have been stimulated by the tissues, thus resulting in elevated ALP activity in the tissues as observed (Umezawa and Hooper, 1982; Malomo et al., 1995).

Aspartate and alanine aminotransferases (AST and ALT) are significant marker enzymes of liver cytolysis and can be employed in assessing liver damage. The activities of AST and

Table 10. Effect of lumefantrine and lumefantrine - copper complex on chromosomal aberration in the liver of $P$. berghei NK-65 infected mice

\begin{tabular}{|c|c|c|c|c|}
\hline Groups & TNMA & MCA & MI & $\% \mathrm{CA}$ \\
\hline $\mathrm{C}$ & $138.00 \pm 12.00^{\mathrm{a}}$ & $2.00 \pm 1.00^{\mathrm{a}}$ & $13.80 \pm 1.20^{\mathrm{a}}$ & $1.53 \pm 0.86^{\mathrm{a}}$ \\
\hline IU & $138.00 \pm 9.00^{\mathrm{a}}$ & $29.50 \pm 2.50^{b}$ & $13.80 \pm 0.90^{\mathrm{a}}$ & $21.35 \pm 0.42^{\mathrm{ab}}$ \\
\hline IC & $142.50 \pm 12.00^{\mathrm{a}}$ & $39.50 \pm 11.50^{\mathrm{b}}$ & $14.20 \pm 1.20^{\mathrm{a}}$ & $28.71 \pm 10.53^{b}$ \\
\hline IL & $138.00 \pm 12.00^{\mathrm{a}}$ & $3.00 \pm 2.00^{\mathrm{a}}$ & $13.80 \pm 1.20^{a}$ & $2.32 \pm 1.65^{a}$ \\
\hline ILC & $139.00 \pm 10.00^{\mathrm{a}}$ & $28.00 \pm 1.00^{\mathrm{b}}$ & $13.90 \pm 1.00^{\mathrm{a}}$ & $20.30 \pm 2.18^{\mathrm{ab}}$ \\
\hline NLC & $143.00 \pm 11.00^{\mathrm{a}}$ & $39.50 \pm 10.50^{b}$ & $14.30 \pm 1.10^{\mathrm{a}}$ & $28.36 \pm 9.53^{b}$ \\
\hline
\end{tabular}


298

ALT in the liver and plasma (Tables 4 and 5) showed significant differences when compared with the control; these may suggest that the integrity of the plasma membrane and amino acid metabolism of these tissues have been compromised (Shahjahan et al., 2004). Lactate dehydrogenase (LDH) is an enzyme that is present in almost all body tissues. It plays an important role in cellular respiration (conversion of glucose from food into usable energy for cells). Increase in the hepatic and plasma activity of the enzyme (Table 6) in both the liver and plasma when compared to the control could be as a result of induction of the enzyme possibly by de novo synthesis (Malomo et al., 1995).

Renal function tests are often employed either to examine the presence or absence of the active laceration in the kidney, or to evaluate the proper functioning capacity of the various parts of the nephron. The main nitrogen-containing metabolic product of protein catabolism and the main catabolic product of muscle metabolism are urea and creatinine respectively; they are employed in the measurement of glomerular filtration rate. The observed difference in the plasma urea and creatinine concentrations (Table 7) when compared with the control may suggest that the drugs, except chloroquine, impaired the clearance function of the kidney.

The propagation of nerve impulses is along the nerve cells and their transmission to receptor cells are influenced by potassium ions. The sodium pump regulates the intracellular $\mathrm{K}^{+}$concentration (of $140 \mathrm{mM}$ ) as against the extracellular $\mathrm{K}^{+}$ concentration (of $5 \mathrm{mM}$ ) (Horton et al., 1993). The difference in concentration of $\mathrm{K}^{+}$(Table 7) observed in the test groups may indicate the interference of the drug with potassium pump, thus interrupting the maintenance of its extracellular concentration. The alteration in the concentration of sodium and bicarbonate ions in the plasma suggested that there was glomerular dysfunction (Tietz et al., 1994). Chloride ion is the most abundant extracellular anion with an extracellular concentration 26 times as much as its intracellular concentration. It has the ability to permeate (by diffusion) the plasma membrane easily and its transport is closely associated with $\mathrm{Na}^{+}$movement. It plays an important role in regulating body $\mathrm{pH}$ levels and also in energy production. An increase in the level of chloride ion concentration in the plasma when compared to the control may be from the influx of $\mathrm{Na}^{+}$pool in body fluids.

In the tropical region of the world, malaria is a chief cause of deaths. In 2010, 219 million cases were reported globally (WHO, 2012). Some of the commonest complications of malaria include haematological changes and are deeply implicated in malaria pathogenesis. The major cell types such as RBCs, leucocytes and thrombocytes are involved in these major changes (Maina et al., 2010; Bakhubaira, 2013; Warimwe et al., 2013; van Wolfswinkel et al., 2013). Malaria patients tended to have significantly lower platelets, WBCs, lymphocytes, eosinophils, RBCs and $\mathrm{Hb}$ level, while monocyte and neutrophil counts are often significantly higher in comparison to non-infected patients (Gerardin et al., 2002; Erhart et al., 2004; Adedapo et al., 2007).

Decrease in haemoglobin levels might be accompanied by a fall in the RBC and PCV (Moss, 1999). The main role of $\mathrm{RBC}$ is haemoglobin transport, which then transfers oxygen from the lungs to the tissues (Waugh and Grant, 2001). The decrease in red cell might be due to the decrease in the production of erythrocytes. It may also show that the drug lacked erythropoietic potentials. Very low levels of red blood cells, haemoglobin and haematocrits can predispose to anaemia (Muhammad and Oloyede, 2009). This might be that the oxygen carrying capacity of the blood and the amount of oxygen delivered to the tissues were reduced by the drug administered. The significant increase in white cells might be an indication that there was a challenge on the immune systems. Increased level of neutrophils may also indicate inflammatory response due to the toxic effect of the drug on the tissues. Neutrophils are mobilised to the location where an injury has occurred within minutes and are the hallmark of acute inflammations (Cohen et al., 2002). Blood indices such as mean corpuscular haemoglobin concentration (MCHC) are of significance in the diagnosis of anaemia in most animals. The significant decrease observed in haemoglobin, PCV, MCH and PLT (Table 8) may suggest that administration of lumefantrine - copper complex have a pathological effect on the blood parameters. Increase in the levels of WBC and LYM when compared to the control may be suggestive of defence mechanism against malaria parasite and/ or lumefantrine - copper complex.

The significant increase in the frequencies of chromosomal aberrations in the mice treated with lumefantrine - copper complex when compared with pure lumefantrine may be that lumefantrine - copper complex is more efficient in the treatment of malaria and may be more likely to increase DNA damage if used over a long period of time. This observation is consistent with the findings reported by Yadav and Trivedi (2009) in which the exposure of Channa punctatus to mercuric chloride, arsenic trioxide and copper sulphate pentahydrate for a week caused chromatid and chromosome breaks, chromatid and chromosome gaps, along with the ring and di-centric chromosomes in the kidney cells. The findings indicate the genotoxic potential of these metals, even in sub-lethal concentrations (Rakshit and Gangopadhyay, 2015). Similar results have also been reported in Swiss albino mice after oral, subcutaneous and intraperitoneal exposures to copper sulphate. Fahmy (2000) reported teratogenic effects of copper in carp at much lower copper concentrations $(0.051$ $\mathrm{mg} / \mathrm{L}$ at $\mathrm{pH} 7.6$ and $0.019 \mathrm{mg} / \mathrm{L}$ at $\mathrm{pH} 6.3$ ) where deformed head, spinal column, upper jaw and a small or absent swim bladder was reported. Copper toxicity is believed to be due to nonspecific binding of the reactive metal cation $\left(\mathrm{Cu}^{2+}\right)$ to biologically important molecules (Rakshit and Gangopadhyay, 2015).

\section{Conclusions}

Mechanochemical synthesis of lumefantrine - copper complex is an environmentally friendly process. The antimalarial activity of the complex investigated using mice infected with $P$. berghei NK-65 showed that the complex exhibited higher anti-malarial activity in comparison with pure lumefantrine and also compared favourably with the standard drug (chloroquine). The biochemical parameters investigated in this study suggested functional and selective toxicity and some chromosomal damage caused by the pure and complex drug; therefore, lumefantrine - copper complex may not be completely safe for repeated oral treatment of malaria. 


\section{Acknowledgements}

This research received no specific grant from any funding agency in the public, commercial, or not-for-profit sectors.

\section{References}

Adebayo JO, Krettli AU (2011). Potential antimalarials from Nigerian plants: A review. Journal of Ethnopharmacology 133:289-302.

Adedapo AD, Falade CO, Kotila RT, Ademowo GO (2007). Age as a risk factor for thrombocytopenia and anaemia in children treated for acute uncomplicated falciparum malaria. Journal of Vector Borne Diseases 44:266-271.

Adewuiyi JO, Olatunji PO (1995). Manual of practical haematology for the MBBS course. University of Ilorin, Ilorin, Nigeria.

Akanji MA, Olagoke OA, Oloyede OB (1993). Effect of chronic consumption of metal bisulphite on the integrity of the kidney cellular system. Toxicology 81:173-179.

Asenso-Okyere K, Asante FA, Tarekegn J, Andam KS (2011). A review of the economic impact of malaria in agricultural development. Agricultural Economics 42:293-304.

Aweeka FT, German PI (2008). Clinical pharmacology of artemisinin-based combination therapies. Clinical Pharmacokinetics 47(2):91-102.

Bakare AA, Okunola AA, Adetunji OA, Jenmi HB (2009). Genotoxicity assessment of a pharmaceutical effluent using four bioassays. Genetics and Molecular Biology 32(2):373-381.

Bakhubaira S (2013). Hematological parameters in severe complicated Plasmodium falciparum malaria among adults in Aden. Turkish Journal of Hematology 30:394-399.

Biot C, Delhaes LA, Maciejewski L, Mortuaire M, Camus D, Dive D, Brocard JS (2000). Synthesis of ferrocene mefloquine and quinine a nalogue as potential antimalarial agents. European Journal of Medicinal Chemistry 35:707-714.

Cave GVW, Raston CL, Scott L (2001). Recent advances in solventless organic reactions: towards benign synthesis with remarkable versatility. Chemical Communications (Cambridge) $7(21): 2159-2169$.

Dormale O, Blaimpain G, Agnaniet H, Nzadiyabi T, Lebibi LA, Maciejewski C, Georges AJ, Millet P (1998). In-vitro antimalarial activity of a new organometallic analogue ferrocene-chloroquine. Antimicrobial Agents and Chemotherapy 42:540.

Erhart LM, Yingyuen K, Chuanak N, Buathong N, Laoboonchai A, Miller RS, Meshnick SR, Gasser RA Jr, Wongsrichanalai C (2004). Hematologic and clinical indices of malaria in a semiimmune population of western Thailand. American Journal of Tropical Medicine and Hygiene 70:8-14.

Fahmy MA (2000). Potential genotoxicity in copper sulfate treated mice, Cytologia 65:235-242.

Gerardin P, Rogier C, Ka AS, Jouvencel P, Brousse V, Imbert P (2002). Prognostic value of thrombocytopenia in African children with falciparum malaria. American Journal of Tropical Medicine and Hygiene 66:686-691.

Kokwaro G, Mwai L, Nzila A (2007). Artemether/lumefantrine in the treatment of uncomplicated falciparum malaria. Expert Opinion on Pharmacotherapy 8:75-94.

Kubowitz K, Ott P (1943). Lactate dehydrogenase activity in the urine. Biochemistry Journal 314:94-96.

Layne SP (2006). Principles of infectious disease epidemiology. Department of Epidemiology EPI 220, UCLA.

Maina RN, Walsh D, Gaddy C, Hongo G, Waitumbi J, Otieno L, Jones D, Ogutu BR (2010). Impact of Plasmodium falciparum infection on haematological parameters in children living in Western Kenya. Malaria Journal 9(3):S4.

Malomo SO, Daramola AS, Balogun EA (1995). Some serum and tissue enzyme changes in mice infected with Plasmodium yoelli nigeriensis before and after administration of halofantrine hydrochloride. Nigerian Journal of Biochemistry and Molecular Biology 10:71-77.

Mikhailanko MA, Shakhtshneider TP, Boldyrev VV (2004). On the mechanism of mechanochemical synthesis of phthalylsulfathiazole. Journal of Malaria Science 39:5435-5439.

Muhammad NO, Oloyede OB (2009). Haematological parameter of broiler chicks fed Aspergillus niger-fermented Terminalia catappa seed meal-based diet. Global Journal of Biotechnology and Biochemistry Research 4(2):169-178.

Murray CJ, Rosenfeld LC, Lim SS, Andews KG, Foreman KJ, Haring D, Fullman N, Naghavi M, Lozano R, Lopez AD (2012). Global malaria mortality between 1980 and 2010: a systematic analysis. Lancet 379(9814):413-431.

Obaleye JA, Caira MR, Tella AC (2009). Synthesis, characterization and crystal structures of the tetrachlorocuprate and tetrabromocadmate salts of the antimalarial mefloquine. Structural Chemistry 20(5):859-868.

Ogunniran KA, Tella AC, Alensela M, Yakubu MT (2007). Synthesis, physical properties, antimicrobial potentials of some antibiotics complexes with transition metals and their effects on alkaline phosphate activities of selected rat tissues. African Journal of Biotechnology 6:1202-1208.

Omari AA, Gamble CL, Garner P (2006). Artemether-lumefantrine (four-dose regimen) for treating uncomplicated falciparum malaria. Cochrane Database Syst Rev. 19(2):CD005965.

Omari AA, Preston C, Garner P (2003). Artemether-lumefantrine for treating uncomplicated falciparum malaria. Cochrane Database Syst Rev.2:CD003125.

Rakshit A, Gangopadhyay K (2015). Study on genotoxic effect of agricultural and industrial effluents on chromosomes of Channa punctatus of polluted water bodies in West Bengal, India. International Journal of Fisheries and Aquatic Studies 3(1):233238.

Reitman S, Frankel S (1957). A colourimetric method for determination of serum glutamate-oxaloacetate and pyruvate transaminase. American Journal of Clinical Pathology (AJCP) 28:56-59.

Ryley JF, Peters W (1970). The antimalarial activity of some quinolone disease. International Society for Clinical Enzymology.

Shahjahan M, Sabitha KE, Malbika J, Shyamala-Devis CS (2004). Effect of Solanum trilobatum against carbon tetrachloride 
300

induced hepatic damage in albino rats. Indian Journal of Medical Research 120(3):194.

Stephens C, Burns RC (2002). Pathways of the pulp, 8th ed. St. Louis, Mosby Inc.

Tella AC, Eke UB, Isaac AY, Ojekanmi CA (2011). Mechanicallyinduced solvent-less synthesis of cobalt and nickel complexes of cimetidine. Orbital - The Electronic Journal of Chemistry 3:94103.

Tella AC, Owalude OS, Simon N, Arise RO (2015). Solid state synthesis of isostructural tetrachlorometallate salts of amodiaquine: crystal structure of $\left[\mathrm{CdCl}_{4}\right]\left[\mathrm{C}_{20} \mathrm{H}_{24} \mathrm{ClN}_{3} \mathrm{O}\right]$. Medicinal Chemistry Research 24:3949-3957.

Tella AC, Isaac AY, Adeniran RA (2011). Mechanochemical synthesis and characterization of 2,4-dinitrophenyl hydrazine metal complexes. International Journal of Applied Chemistry $7(3): 25-32$.

Tietz NW (1990). Clinical Guide to laboratory tests, 2nd edition, W.B. Saunders, Philadelphia.

Umezawa H, Hooper IR (1982). Amino glycoside antibiotics. Springer-Verky, Berlin, Haldelberg.

Van Wolfswinkel ME, Vliegenthart-Jongbloed K, De Mendonca MM, Wever PC, McCall MB, Koelewijn R, Van Hellemond JJ, Van Genderen PJ (2013). Predictive value of lymphocytopenia and the neutrophil-lymphocyte count ratio for severe imported malaria Malaria Journal 12:101.

Warimwe GM, Murungi LM, Kamuyu G, Nyangweso GM, Wambua J, Naranbhai V, Fletcher HA, Hill AV, Bejon P, Osier $\mathrm{FH}$, Marsh K (2013). The ratio of monocytes to lymphocytes in peripheral blood correlates with increased susceptibility to clinical malaria in Kenyan children. PLoS One 8:e57320.
WHO: World malaria report 2012 (2012). Geneva: World Health Organization.

WHO: World Malaria Report 2013 (2013). Geneva: World Health Organization.

WHO: World Malaria Report 2014 (2014). Geneva: World Health Organization.

WHO: World Malaria Report 2015 (2015). Geneva: World Health Organization.

Wright PJ, Plummer DJ (1974). The use of urinary enzymes measurement to detect renal damage caused by nephritic compounds. Biochemical Pharmacology 23:65-75.

Yadav KK, Trivedi SP (2009). Chromosomal aberrations in a fish, Channa punctata after in vivo exposure to three heavy metals. Mutation Research 678:7-12. 